\title{
Discussion on Textual Equivalence-Mona Baker's In Other Words: A Course Book on Translation
}

\author{
Jiaojiao Zhuang \\ School of Foreign Languages, East China University of Science and Technology, Shanghai, China \\ Email: 572959292@qq.com
}

How to cite this paper: Zhuang, J.J. (2021) Discussion on Textual Equivalence-Mona Baker's In Other Words: A Course Book on Translation. Open Access Library Journal, 8: e8103.

https://doi.org/10.4236/oalib.1108103

Received: October 20, 2021

Accepted: October 24, 2021

Published: October 27, 2021

Copyright $\odot 2021$ by author(s) and Open Access Library Inc.

This work is licensed under the Creative Commons Attribution International License (CC BY 4.0).

http://creativecommons.org/licenses/by/4.0/

\section{(c) (i) Open Access}

\begin{abstract}
In Other Words: A Course Book on Translation aims to provide a basis for guiding translators. The abundant examples and detailed explanations make the book easy to be perceived. However, Baker comments that in Chinese pronouns are hardly used and once a participant is introduced, continuity of reference is signalled by omitting the following subjects of following clauses. By qualitative analysis, this paper finds that although Chinese has a tendency to use fewer pronouns than English, the cases it uses pronoun are not that rare.
\end{abstract}

\section{Subject Areas \\ Languages \& Translation}

\section{Keywords}

A Course Book on Translation, Mona Baker, Translation,

Textual Equivalence

\section{Brief Introduction on In Other Words: A Course Book on Translation}

Mona Baker is a professor of translation studies and Director of the Centre for Translation and Intercultural Studies at the University of Manchester in England. She is the founder of ST. Jerome Publishing. She was editorial director until 2014 when Routledge bought the St. Jerome catalogue. She is also the founder of the international journal The Translator.

In Other Words. A Course Book on Translation is the first book of Mona Baker on translation, which discusses the equivalence at the level of the word, 
above-word, grammar, thematic structure, cohesion and pragmatic levels. According to Baker, this book "attempts to explore some areas in which modern linguistic theory can provide a basis for training translators and can inform and guide the decisions they have to make in the course of performing their work" [1]. This book looks at translation mostly through the perspective of linguistics, with some theories of Halliday's systemic functional linguistics.

With the general approach of bottom-up, most chapters revolve around the equivalence of lexical, grammatical, textual and pragmatic. There are seven chapters in the 2001 version. The opening chapter introduces the framework and intention of the book. Chapter 2 deals with the equivalence at the word level. She tries to define the definition of "word" which applied to all languages. She lists 11 types of non-equivalence, for example, culture-specific concepts. The source-language concept is not lexicalized in the target language; and she also provides eight strategies to deal with these problems, such as translating by a more general word (superordinate), translating by a more neutral/less expressive word. In Chapter 3 she moves on the equivalence above word level. She broadens the view into collocation, idioms, and fixed expressions and discusses the difficulties and strategies of translation of them. Chapter 4 goes up to the level of grammatic equivalence. This chapter transits the lexical equivalence to the textual equivalence. Four topics are involved: 1) differences between lexical and grammatical categories, 2) the diversity of grammatical categories across languages, 3) word order, and 4) discourse organization. Chapter 5 and Chapter 6 treat the equivalence of textual. Text is a meaning unit, not a form unit, but meaning is realized through form and without understanding meanings of individual forms that one cannot interpret the meaning of the text as a whole [1]. Out of context, translating words or sentences is completely a futile exercise. Chapter 5 pays attention to thematic and information structures. First she overviews Hallidayan approaches to information flow, then she talks about word order as a textual strategy (rather than a grammatical feature) and explores a number of ways in which its role in controlling information flow can be explained [1]. Chapter 6 focuses on cohesion. Baker resumes her discussion of translation difficulties and strategies at the level of text by looking at cohesion, the second feature of text organization. She uses many examples to clarify five main cohesive devices in English, which are identified by Halliday and Hasan, those are reference, substitution, ellipsis, conjunction, and lexical cohesion. Chapter 7 contributes to pragmatic equivalence. She concludes her "discussion of language and translation with a brief look at how a given text comes to 'make sense' to a given readership" [1]. Coherence and implicature are two main topics.

Mona Baker's perspective of translation is more linguistic and descriptive. She specifies the equivalence theory posed by Nida and gives the standard of translation quality assessment. She says in her book that the role of translator should be more visible, and in the future translation should connect more and more with humanity. In the newest version of In Other Words, Baker adds a new chapter 
on translation ethics, while we will not discuss translation and humanity in this paper. Translation is a very young discipline in academic terms. In the translation of film subtitles, more and more people find the importance of context, because in different context words may have different meanings. In this book, Baker also pays great attention to textual equivalence. To the same problem, linguists usually have their own opinions. To the equivalence, Baker prefers to use examples and analyzes according to Halliday's systemic functional grammar. There must be various kinds of "non-equivalence", which can be understood as a contrastive difference. However, there is no theoretical discussion of the problematic concept of equivalence itself, or of the debates on its interpretation and relevance within Translation Studies [2]. Baker clarifies [1] that "the strategies are not preconceived, nor are they suggested as ideal solutions; they are identified by analyzing authentic examples of translated texts in a variety of languages and presented as 'actual' strategies used rather than the 'correct' strategies to use." Therefore her perspective is descriptive and problem-based [2].

One of the attractive features of this book is its illustrative examples. These examples are drawn from over fifty different languages, including Chinese, Japanese, French, German, and Arabic. As an Arab-English, Baker discusses Arabic to English or English to Arabic in great detail. In the preface, she admits that her knowledge of other languages is limited, and her comments on other languages heavily rely on the expertise of other specialists. John D. Gallagher complains [3] that Baker's analyses of her exemplificatory material are not exempt from occasional lapses. On p. 69, he says [3] that Baker overlooks the fact that the French idiomporter de $I^{\prime}$ eau à la rivière went out of use at least 70 years ago. On p. 158, he says [3] that Baker affirms that "a French verb has to be accompanied by an immediate subject". Baker has overlooked the fact that the prop il subject is often omitted before the impersonal verb falloir in spoken French. Similarly, Baker's acuteness to Chinese is a little bit weaker than her acuteness to English and Arabic. Based on In Other Words, this paper will pay attention to contrastive differences between Chinese and English on the textual level.

This paper then will firstly introduce Baker's main views on textual equivalence, and discuss her comments on Chinese translation. We find that some comments or conclusions she made may not that strict; therefore we compare translations by specific example to illustrate our ideas.

\section{Baker's Main Views on Textual Equivalence}

Mona Baker in the book of In Other Words defined six types of equivalence: (1) equivalence at word level, (2) equivalence above the word level, (3) grammatical equivalence, (4) textual equivalence; thematic and word order, (5) textual equivalence; cohesion, and (6) pragmatic equivalence. Textual equivalence refers to the equivalence in terms of information and cohesion. It is up to the translator to decide whether or not to maintain the cohesive ties as well as the coherence of the source language [3]. We can explore textual equivalence from the 
aspect of reference, substitution and ellipsis, conjunction and lexical cohesion.

Chapter 5 applies the systematic approach to thematic structure. Baker makes use of Hallidayan linguistics to examine translation as communication within a sociocultural context [4]. Halliday put forward the "register" concept in his model of language. In SFL register is a technical term, richer and more complex [4]. It links the variables of social context to language choice and comprises three elements: field, tenor and mode. Field refers to what is being written about; tenor means who is communicating and to whom; mode is the form of communication. Each of the variables of Register is associated with a strand of meaning in the text. These three strands, known as "metafunctions", are ideational, interpersonal, and textual. Clause as a message can be analyzed in terms of two types of structure: thematic structure and information structure [1]. Mona Baker outlines two main approaches to the analysis of clauses as a message. One is the Hallidayan approach, which treats thematic and information structures separately. Another is from Prague School, they conflate the two structures and combine them in the same description. Halliday's notion of theme reflects the special characteristics of Chinese and English. We only talk about the Hallidayan approach in this paper, because we discuss Chinese and English contrastive differences in textual level.

A clause consists of two segments: theme and rheme. The theme is what the clause about. It has two functions: (a) it acts as a point of orientation by connecting back to previous stretches of discourse and thereby maintaining a coherent point of view and, (b) it acts as a point of departure by connecting forward and contributing to the development of later stretches. The rheme is what the speaker says about the theme. It is the goal of discourse. As such, it is the most important element in the structure of the clause as a message because it represents the very information that the speaker wants to convey to the hearer. It is the rheme that fulfils the communicative purpose of the utterance [1]. The notions of subject and predicate can be used to account for the grammaticality, while the notions of theme and rheme can be used to account for the acceptability of a given sequence in a given context. Baker emphasizes that translators should not underestimate the cumulative effect of thematic choices on the way we interpret text [1]. For a translator, it is important to be aware of the relative markedness of the thematic and information structures. The thematic choice involves selecting a clause element as a theme. In the Hallidayan model, thematic choices are expressed by placing one of these elements in initial position in the clause. Thematic choices indicate the speaker's/writer's point of departure. The fewer choices a clause has, the less marked it will be and the weaker will be its meaning. And the less expected a choice, the more marked it is and the more meaning it carries. Hallidayan linguists identify three main types of marked themes in English: fronted theme, predicated theme, and identifying theme. From the view of themes, the nature of English exists relatively fixed word order; and Chinese exists a special category of the topic that always appears in the first 
place of the clause [1]. Actually, it is disputable that the topic in Chinese "always" occurs at the beginning of the clause. We will discuss in the next part. The distinction between theme and rheme is speaker-oriented, while the distinction between what is given and what is new in a message is hearer-oriented. According to Halliday and Hasan [5], information structure is only of spoken English.

Chapter 6 applies the systematic approach to cohesion. Cohesion is the second feature of text organization and the network of lexical, grammatical, and other relations which provide links between various parts of a text. Cohesion is different from coherent, which is a surface relation. It is cohesive devices that connect the actual words and expressions which we can see or hear. Baker uses the model in Halliday and Hasan's Cohesion in English (1976). As Halliday and Hasan state that there are five main cohesive devices in English: reference, substitution, ellipsis, conjunction, and lexical cohesion.

Reference should be understood from the perspective of semantics where meaning needs to be interpreted through reference to something else. Reference is used to discern the relationship of identity, which holds between two linguistic expressions rather than a direct relationship between words and extra-linguistic objects. In the textual level, every language has words or phrases that can be used to refer. In most language, especially English, the pronouns take a large part of words. Personal references and demonstrative references are to establish similar links between expressions in an English text. By references, the reader or hearer can trace participants, entities, events, etc. in a text. Baker cites Halliday and Hasan's view that the relationship of reference may be established situationally [1]. The situation or context is different from person to person. Therefore, it may be harder for translators to identify a chain of co-referential items. Hoye supports this view by saying "co-reference 'is not strictly a linguistic feature at all but a matter of real-world knowledge'." However, those aims of translating might be different; it is difficult to draw a line between what is linguistic or textual and what is extralinguistic or situational. Each language has what we might call general preferences for certain patterns of reference as well as specific preferences that are sensitive to text type [1]. English tends to depend heavily on pronominal references in tracing participants. Baker states that in Japanese and Chinese, pronouns are hardly ever used and, once a participant is introduced, continuity of reference is signalled by omitting the subjects of following clauses.

Substitution is a grammatical substitution within the text and ellipsis is a kind of zero substitution, where an element needs to be supplied, both of them are of grammatical relationships. There are no obvious boundary lines between these three types of cohesive devices. Every language has its own cohesive devices to establish links between textual elements, what a translator should do is to reestablish the way that creating links according to textual norms of the target language. What is more, translators should take both language and text-type preference into consideration.

Conjunction is a semantic relation indicating how what follows is linked to 
what has gone before. The main relations are additive, adversative, causal, temporal and continuatives. According to Baker, there are three important points: First, the same conjunction may be used to signal different relations, depending on the context. Second, these relations can be expressed by a variety of means. Third, conjunctive relations do not just reflect relations between external phenomena, but may also be set up to reflect relations which are internal to the text or communicative situation [1]. Different languages have different types of conjunctions they prefer to use, and different frequencies they use such conjunctions. According to Baker, Chinese and Japanese prefer to use simpler and shorter structures and to mark the relations between these structures explicitly where necessary. Even in the same language, take English as an example, different genres of English have different preferences for types of conjunction. Translators should bear in mind that the adjustments in translation will often affect the content and the line of argumentation.

Lexical cohesion is a lexical relation where cohesion is produced by the selection of vocabulary; these can be through reiteration and collocation. Lexical cohesion is not a relation between pairs of words as the above discussion might suggest. On the contrary, lexical cohesion typically operates through lexical chains that run through a text and are linked to each other in various ways [1]. The notion of lexical cohesion is important because it determinates the existence of the network of lexical words instead of a specific class or type of words. The network of lexical words provides cohesion as well as determinates collectively the sense in which each individual item is used in a given text. The lexical network in target language usually is close to source language when dealing with non-literary translations. Then cohesiveness and coherence depend on the skills and experiences of translators.

All in all, the overall level of cohesion may also vary from one language to another; even within the same language, different texts will vary in the density of their cohesive ties [1]. Raising the level of explicitness is a general tendency in translation. Then increasing explicitation of cohesive ties may even be a general strategy adopted by all translators.

\section{Analysis on Baker's Comments on Chinese Translations}

Baker's statements and descriptions are easy to understand by using specific examples. Her views on Chinese are mainly from works of others rather than analysis like she does on Arabic. Therefore some comments or conclusions she made may not be that strict.

On p. 185, Baker says that in Japanese and Chinese, pronouns are hardly ever used and, once a participant is introduced, continuity of reference is signaled by omitting the subjects of following clauses.

There are many kinds of pronouns: demonstrative pronouns, personal pronouns, interrogative pronouns, possessive pronouns, relative pronouns and so forth. Pronouns actually are used a lot in Chinese while different pronouns will 
have different features. We will discuss the first two mentioned pronouns separately in the below parts.

\section{(1) Demonstrative pronouns}

Demonstrative pronouns are pronouns used to replace nouns or noun phrases in a sentence, representing that which is nearby or far away in space or time. Because demonstrative pronouns are less specific than the nouns or noun phrases they replace, people must use context to clarify what is being referred to. In spoken language, this can mean having to gesture toward, point to, or look at the thing or things indicated by the demonstrative pronoun. In written text, demonstrative pronouns are usually used to refer to previously mentioned things, ideas, or topics. To some extent, both Chinese and English demonstrative pronouns are influenced by subjective feeling. "This" and "这 (Zhè)" are often used to express positive feelings, while "that" and “那 (Nà)" are often to express negative feelings. Compared with English, Chinese has more tendency to be influenced by these feelings. Wang Jianguo says [6] that the awareness of the boundary between subject and object is not clear enough for native Chinese speakers; while for native English speakers, it is relatively clear. Consider following examples:

\section{Source Text:}

我怎能忘记那美丽的校园呢?

那儿处处是碧绿的芳草, 绿草中铺着洁白的、笔直的石路。路两旁种的那 些树分明是一品红, 然而原该为大红色的排列为环状的叶, 却变为柔媚的粉 红, 还有着淡绿色的边儿。我常在这条长长的石径上散步。走着走着, 来到 一座宽阔的台子上, 站在这里可以看到迷人的晚霞与夕照, 偶然也能看到冒 着浓烟鸣鸣南去的列车。转身往回走, 不远便会来到实验室和图书馆。这儿 宽大的落地窗软窝垂地, 窗外的木棉树上开着耀眼的红花。再往前走便是餐 厅了, 那儿有一株美丽的树, 开着雪一样白的花儿。那花儿开得轻柔而又昫 娜, 一朵朵地连成一片, 从远处看去, 美得像新嫁娘雪白的头纱。后来我才 知道这就是我在书上读到那么多次的曼陀罗。

(Wǒ zěnme néng wàngjì nà měilì de xiàoyuán ne?

Nà biān chùchù shì bìlù de fāng căo, lù căo zhōng pùzhe jiébái de, bǐzhí dì nàxiē shù lù. Fěnhóng, hái youuzhe dàn lüsè de biān er. Wǒ cháng zài zhăng zhăng de shí jìng shàng sàn kāi. Zǒuzhe zǒuzhe, lái dào kuānkuò de táizi shàng, zhànzhe kěỹ kàn dào mírén de wănxiá yǔ xìzhào, ǒurán yě néng kàn dào màozhe nóng yān wū wū nán qù de huǒchē. Xuánzhuăn wăng zǒu, bù yuăn huí dào dà shíyàn shì hé túshū guăn. Zhèlǐ de luòdì chuānglián ruăn chuí de, chuāngwài de mùmián shù shàng kāizhe yàoyăn de hóng. Huā. Zài wăng qián zǒu jiùshì cāntīngle, nà biān yǒuyĩ zhū měilì de shù, kāizhe xuěbái de huā er. Qù, měi dé xiàng xīn jià niáng xuěbái de tóu shā. Yĩ hòu wǒ cái cái zhīdào zhè jiùshì wǒ zài shū shàng dú dào nàme duō cì de màn tuó luó.)

\section{Target Text:}

How can I ever forget the beautiful campus in Africa?

The grounds were covered with dark green grass through which stretched a 
straight white stone path. On both sides of the path were planted what I believed to be poinsettias. Now the flowers were surrounded by pinkish leaves instead of bright red ones as they should have been. Trimmed with light green edges, the leaves looked delicate and charming. Along the long path I often took a stroll which would take me to a wide terrace, where I could watch the enchanting glow of sunset, and occasionally catch the sight of a train pulling and hooting on its way southward. On my way hack I would pass by the laboratory and library building whose large French windows had soft curtains let fall to the floor. Just outside the windows kapok flowers glowed red in full bloom. A short way off stood the dining hall, where I found a tree hearing snore-white blossoms so graceful and soft to the touch. Viewed together from the distance, they were as beautiful as a bridal veil. Later I learned that it was a tree called datura which I had so often read about in hooks. (Selected from Anthology of Chinese and English Prose)

To make it more clear, I make Table 1 to compare the differences.

It's clear that the English target text specified demonstrative pronouns by adding more information. In other words, Chinese demonstrative pronouns are more abstract in semantic meaning. The reader has to supply all the missing subjects and create his/her own chains of reference [1]. In Example 1, in the whole context, there is no word to show the campus is in Africa. The translator makes the place explicit. Also, we can see the different psychological distances between the two languages. In Chinese, the standpoint can be moved according to speaker or hearer's psychological activity; while in English the stand is fixed and psychological distances often determined by actual space. Therefore, when we translate Chinese to English, we need to extend the information that is compressed in Chinese [6].

Table 1. Comparison on Chinese-English.

\begin{tabular}{|c|c|c|c|}
\hline Example & ST & Transcript & TT \\
\hline 1 & 那美丽的校园 & Nà měilì de xiàoyuán & The beautiful campus in Africa \\
\hline 2 & 那儿处处是碧绿的芳草 & Nà chùchù shì bìlü de fāng căo & $\begin{array}{c}\text { The grounds were covered with } \\
\text { dark green grass }\end{array}$ \\
\hline 3 & 路两旁种的那些树 & Lù liăngpáng zhǒng dì nàxiē shù & $\begin{array}{l}\text { On both sides of the path were } \\
\text { planted what... }\end{array}$ \\
\hline 4 & 沿着这条长长的石径上 & $\begin{array}{l}\text { Yánzhe yuánshǐ zhăng zhăng de shí jìng } \\
\text { shàng }\end{array}$ & Along the long path... \\
\hline 5 & 站在这里可以看到 & Zhànnèi kěyǐ kàn dào & a wide terrace, where I could watch \\
\hline 6 & 这儿宽大的落地窗软帘垂地 & $\begin{array}{l}\text { Zhè biān kuāndà de luòdìchuāng ruăn } \\
\text { lián chuí de }\end{array}$ & $\begin{array}{l}\text { the laboratory and library building whose } \\
\text { large French windows had soft curtains let } \\
\text { fall to the floor }\end{array}$ \\
\hline 7 & 那儿有一株美丽的树 & Nà li yǒuyī zhū měilì de shù & the dining hall, where I found a tree \\
\hline 8 & 那花儿开得 & Nà huā er kāi dé & the dining hall, where... \\
\hline
\end{tabular}




\section{(2) Personal pronouns}

A personal pronoun is a pronoun that refers to a particular person, group, or thing. Like all pronouns, personal pronouns can take the place of nouns and noun phrases. In the system of reference, only the third personal pronouns have the property of cohesive function in text, which is essential for the cohesion and coherence of text [7]. Shao also says [7] English texts use the third personal pronouns than Chinese. Therefore Baker says "Chinese pronouns are hardly ever used" is not totally correct. There is an omission of the subject in Chinese when a participant is introduced, but this also happens in English, which just has a lower frequency of using than Chinese. Consider the following example:

\section{Source Text:}

You hear it all along the river. You hear it, loud and strong, from the rowers as they urge the junk with its high stern, the mast lashed alongside, down the swift running stream. You hear it from the trackers, a more breathless chaunt, as they pull desperately against the current, half a dozen of them perhaps if they are taking up a wupan, a couple of hundred if they are hauling a splendid junk, its square sail set, over a rapid. On the junk, a man stands amidships beating a drum incessantly to guide their efforts, and they pull with all their strength, like men possessed, bent double; and sometimes in the extremity of their travail they craw on the ground, on all fours, like the beasts of the field. They strain, strain fiercely, against the pitiless might of the stream. The leader goes up and down the line and when he sees one who is not putting all his will into the task he brings down his split bamboo on the naked back. Each one must do his utmost or the labor of all is vain. And still they sing a vehement, eager chaunt, the chaunt of the turbulent waters. I do not know how words can describe what there is in it of effort. It serves to express the straining heart, the breaking muscles, and at the same time the indomitable spirit of man which overcomes the pitiless force of nature. Though the rope may part and the great junk swing back, in the end the rapid will be passed; and at the close of the weary day there is the hearty meal and perhaps opium pipe with its dreams of ease. (Selected from The Song of The River by W. Somerset Maugham)

\section{Target Text:}

沿着河流一路都可以听到这歌声。这是桨手的歌声, 响亮有力。他们奋力 地划着木船, 顺急流而下, 船尾尧得老高, 桅杆猛烈地摆动。这是纤夫的号 子声, 他们在拼尽全力逆流拉船时, 声音会更加急促, 让人透不过气来。如 果拉的是乌篷船, 那可能有十几个人; 如果拉的是扬着横帆的华丽大木船过 急流, 那就得有几百人。船中央站着一个汉子不停地击鼓, 给他们助威, 让 他们使劲。于是纤夫们使出浑身气力, 就像被魔咒驱使般, 腰弯成了九十度。 有时在极度费力的情况下, 他们就全身趴地匍匐前进, 像地里的牲口。顶着 河水无情的阻力, 他们拉呀, 拉呀, 拼命地拉。领头的在队伍前后来回奔走, 看到有人没有拼尽全力, 就用擘开的竹条抽打他们裸露的脊梁。每个人都必 须全力以赴, 否则所有的努力就白费了。就这样他们还唱着激昂又热切的号 子, 这是汹涌澎看的河水的号子。我不知道如何用言语来描述这股劲儿, 这 
里面带着心脏的拉扯, 肌肉的撕裂, 还有人们克服无情大自然时所表现出的 不屈不挠的精神。虽然绳子可能断开, 大船可能又会被荡回, 但他们最终能 涉过湍流, 在疲㤂的一天结束后, 热闹地吃上一顿饱饭, 也许还可以抽一枪 鸦片, 舒服地幻想一番。(Translated by Luo Xuanming)

(Yán gē yīlù yīlù dōu shì zhè èrguāng. Zhè shì jiăng de gēshēng, xiăngliàng kěyǐ zhuóshǒu. Tāmen fènlì de mù mù, jíliú ér xià, chuánwěi shùn qiào dé gāo, gān gān měngliè de xuánzhuăn. Qiànfū de hào zi shēng, tāmen zài pīn jìn quánlì nìliú lā chuán shí, huì gèngjiā jícù, gēnghuàn bùguò lái. Mùchuán jíliú, biàn dé yǒu yăng rén. Chuán zhànzhe yīgè hànzi bù tíng de jī gǔ, gěi tāmen zhùwēi, ràng tāmen sȟ̃jìn zhōngyāng. Yúshì qiànfūmen shǐ chū húnshēn qì̀̀, jiù xiàng bèi mó zhòu qūshǐ bān, yāo wān yǒushí zài jídù fèilì de qíngkuàng xià, tāmen jiù quánshēn pā de púfú qiánjìn, xiàng dì li de shēngkǒu. Dǐngzhe héshuǐ wúqíng de bódòng, tāmen ya, pīn lā lā lā, tāmen ya, ya, mìng de. Lĩ ngtóu de gūlínglíng de tāmen yǐhòu láihuí bēnzǒu, kàn dào méiyǒu pīn jìn quánlì, jiù yòng pī kāi de zhú tiáo chōu tāmen luǒlù zìjī de jĩ liang. Měi gèrén dōu bìxū quánlì yĩ fù, fǒuzé suǒyǒu de nǔlì jiù báifèile. De hào zi, zhè shì xiōngyǒng péngpài de péngpài de shuǐ de hào zi. Suīrán shéng zĩ kěnéng huì huài diào, dàchuán kěnéng yòu bèi dàng huí, dàn tāmen zuìzhōng shèguò xuánwō, zài huíyì de jiéshù hòu, kuánghuān de chī shàng tou năo băo fàn, kěnéng hái kěỹ chōu yī qiāng yāpiàn, shūfú de huànxiăng yī fān.)

Most subjects of this text are those "rowers". There are 24 third personal pronouns in the source text, while in the target text there are 9 third personal pronouns. Xu Yucheng [8] used corpus to prove that English uses twice more pronouns than Chinese, and argues that this phenomenon should be due to the pronoun "the" in English which is a difficult point for Chinese to grasp. Shao Zhihong gives two situations where pronouns should be omitted as much as the text can: (1) Chinese tends to omit possessive pronoun as much as possible; if not, the "的 (de)" should try to be omitted; (2) If the coherence can be maintained, then pronouns can be replaced by zero anaphora [7]. We further discuss the below sentences:

Table 2. Comparison on English-Chinese

\begin{tabular}{|c|c|c|c|}
\hline Example & ST & $\mathrm{TT}$ & Transcript \\
\hline 9 & $\begin{array}{l}\text { On the junk, a man stands amidships } \\
\text { beating a drum incessantly to guide } \\
\text { their efforts, and they pull with all } \\
\text { their strength, like men possessed, bent } \\
\text { double; and sometimes in the extremity } \\
\text { of theirtravail they craw on the } \\
\text { ground, on all fours, like the beasts of } \\
\text { the field. }\end{array}$ & $\begin{array}{l}\text { 船中央站着一个汉子不停地击鼓, } \\
\text { 给他们助威, 让他们使劲。于是 } \\
\text { 纤夫们使出浑身气力, 就像被魔咒 } \\
\text { 驱使般, 腰弯成了九十度。有时在 } \\
\text { 极度费力的情况下, 他们就全身 } \\
\text { 跈地匍匐前进, 像地里的牲口。 }\end{array}$ & $\begin{array}{c}\text { Chuán zhōngyāng zhànzhe yīgè hànzi } \\
\text { bù tíng de jī gǔ, gěi tāmen zhùwēi, ràng } \\
\text { tāmen shǐjìn. Yúshì shēn qiànfū shǐ } \\
\text { chū húnshēn qìlì, jiù xiàng bèi mó zhòu } \\
\text { qūshǐ bān, yāo wān chéngle jiǔshí dù. } \\
\text { Yǒushí zài jí fèilì de qíngkuàng. Xià, } \\
\text { tāmen jiù quánshēn pā de púfú qiánjìn, } \\
\text { xiàng dì li de shēngkǒu. }\end{array}$ \\
\hline 10 & $\begin{array}{c}\text { You hear it all along the river. You } \\
\text { hear it, loud and strong... }\end{array}$ & $\begin{array}{c}\text { 沿着河流一路都可以听到这歌声。 } \\
\text { 这是桨手的歌声，响亮有力。 }\end{array}$ & $\begin{array}{c}\text { Yīlùshàng yī lù dōu tīng dào zhè shǒu } \\
\text { jiăng de gēshēng, xiăngliàng de } \\
\text { shēngyīn. }\end{array}$ \\
\hline
\end{tabular}


In the source text, there is only a long sentence, while translator divides the whole sentence into three small sentences. We can see clearly from the text that the rowers are participants. Chinese is parataxis-prominent and tends to be confused by the boundary of individual consciousness and integral consciousness [6]. So understanding Chinese depends more on context. As shown in Table 2, example 9 omits two possessive pronouns "their" just like situation 1, which put forward by Shao Zhihong. Example 10 omits the pronouns which act as objects just like situation 2 .

\section{Conclusions}

This paper further discusses the vague part of Baker's translation view in textual equivalence. In the book, Baker states that Chinese are hardly ever used; therefore this paper discusses the cases where pronouns are used. Although there is a tendency to use fewer pronouns than in English, the case using pronouns is not that rare. From expertises of other scholars, English uses pronouns more than twice as often as Chinese does. Therefore, it is not that Chinese hardly use pronouns but it is the problem of frequency. Baker says in Chinese, once a participant is introduced, continuity of reference is signalled by omitting the subjects of the following clause. This paper gives two situations where the reference is omitted, and added object will also be omitted if the coherence can still maintain. The limited examples in this paper may cause the limitation of the conclusion, thus later study may resort to the tool of corpus to further explore the phenomena of pronoun usage across Chinese and English.

Anyway, In Other Words is a richly rewarding book which provides a great amount of information and valuable insights. Moreover it does have some influence on translation studies. This paper generally provides a critical review of the book and challenges some ideas reasonably, which will open a critical idea for further study in this field.

\section{Conflicts of Interest}

The author declares no conflicts of interest.

\section{References}

[1] Baker, M. (2001) In Other Words: A Course Book for translation. Routledge, New York.

[2] Andrew, C. (2012) Mona Baker: In Other Words: A Course Book on Translation. Target, 24, 191-193.

[3] Gallagher, J.D. (1994) Mona Baker: In Other Words: A Course Book on Translation. Babel, 40, 249-252. https://doi.org/10.1075/babel.40.4.16gal

[4] Jeremy, M. (2016) Introducing Translation Studies: Theories and Applications. Routledge, London \& New York.

[5] Halliday, M.A.K. and Hasan, R. (1976) Cohesion in English Longman, London and New York.

[6] Wang, J.G. (2019) Translation of Chinese-English-Fundamental Theory and Prac- 
tice. ZhongYi Press, Beijing. (In Chinese)

[7] Shao, Z.H. (2013) C-E Translation Studies: A Contrastive Approach. East China University of Science and Technology Press, Shanghai.

[8] Xu, Y.C. (1996) A Comparative Analysis of the Main Cohesive Device in English and Chinese. Shandong Foreign Languages Journal, No. 4, 1-6. (In Chinese) 